\title{
Hydrolysis of Polymeric Esters with Polymeric Sulfonic Acids
}

\section{Hydrolysis of Partially Acetylated Polyvinyl Alcohol with Various Polymeric Sulfonic Acids}

\author{
By Ichiro Sakurada*, Yasuhiro Ohmura* and Yasuyoshi Sakaguchi**
}

\begin{abstract}
Partially acetylated polyvinyl alcohols of different degrees of acetylation were hydrolyzed with various polymeric sulfonic acids in aqueous solutions, and the rate constants of hydrolysis $\left(\boldsymbol{k}_{s}\right)$ were compared to those of hydrolysis carried out under the same condition with hydrochloric acid $\left(k_{\mathrm{HCl}}\right)$. The ratio $r=k_{s} / k_{\mathrm{HCl}}$ was dependent not only on degrees of sulfonation but also on preparation conditions of sulfonated polystyrene and polystyrene sulfonic acid. The effect of polymerization degree of these sulfonic acids on their catalytic action was slight. The polymer sulfonic acids containing highly hydrophobic groups showed much greater $r$-values than unity, but the order of $r$-values could not be explained only by the hydrophobic nature of the polymers. Some discussions were given for the results.
\end{abstract}

第 3 報 改質ポリビニルアルコールおよびデンプンの部分アセチル化物の加水分解

(1966 年 3 月 31 日受理)

\author{
桜田一郎***.大村恭弘***. 坂口康 義****
}

\begin{abstract}
要 旨 分枝ポリビニルフルコール (PVA) (分枝単位: 1.3 個以下 $/ 100$ 基本分子),ビニルアルコ ールーフリルアルコール共重合物 (フリルフルコール含量: 22 モル \%以下), ビニルフルコールーイン プロペニルアルコール其重合物（イソプロペニルアルコール含量：18モル％以下）の部分アセチル 化物を，ポリスチレンスルホン酸，部分スルホン化ポリスチレン，ドデシルベンゼンスルホン酸な どを触媒に用いて水溶液中でケン化し，反応の速度定数 $\left(k_{s}\right)$ を塩酸触媒の場合のそれ $\left(k_{\mathrm{HCl}}\right)$ と比較 した。これらの改質 PVAの部分丁セチル化物に対する $r=k_{s} / k_{\mathrm{HCl}}$ の值は, 一般に直鎖状の非改質 PVAの部分厂セチル化物に対する值に近かった。部分アセチル化デンプンの加水分解も検討した が，r值はアセチル化 PVA の場合よりもずっと小さく(平均值 2), 部分アセチル化アミロースの ほうが部分てセチル化アミロペクチンよりやや大きかった。これらの結果について少し考察した。
\end{abstract}

\section{1. 緒言}

第 1 報1) および第 2 報2)において，種々の高分子スル ホン酸を触媒に用いて，部分了セチル化ポリビニルアル ユール(Ac-PVA)を水溶液中でヶン化し，ケン化速度に 及ぼすAc-PVAの重合度, ア七チル化度，てセチル基の 配列状態, 立体規則性などの構造の影響, 高分子スルホ ン酸の構造および反応条件の影響について検討した。そ の結果, 適当な高分子スルホン酸はこの反応に対して塩 酸よりもずっ上大きい触媒作用を示すことを認め，これ は高分子ェステルと高分子触媒との間に疎水性結合が起 こるために，高分子近傍にエステル基とスルホン酸基の
両者が濃縮化されることに基くと結論している。 本報においては, これらの実験に引き続いて, 高分子 エステルの構造の影響についてさらに若干の検討を行な った。すなわち, Ac-PVA 分子中の比較的少量の分枝, フリルフルコールあるいはイソプロペニルフルコール単 位の存在が，高分子スルホン酸触媒によるケン化速度に 及ぼす影響を調べた。また，PVA と同じく高分子てル コールであるが，骨格構造が著しく異なるデンプンの部 分アセチル化物 (Ac-S)についても同様な実験を行ない, Ac-PVA の場合と比較検討した。さらに, 著者らはAcPVA のケン化に対して適当な長鎖フルキル基を含む低 分子スルホン酸も塩酸よりずっと大きい触媒作用を示す

* Department of Polymer Chemistry, Kyoto University (Kyoto)

** Department of Applied Chemistry, Kōnan University (Higashinada-ku, Kōbe)

*** 京都大学工学部高分子化学教室 (京都市左京区吉田本町)

**** $\quad$ 甲南大学理学部応用化学教室 (神戸市東潄区本山町岡本) 
ことを認めているのでタ，このようなスルホン酸の改質 PVA およびデンプンの部分アセチル化物のケン化反応 に対する触媒作用についても, Ac-PVA の場合と比較検 討した。

\section{2. 実験}

\section{1 高分子ェステル}

分枝 Ac-PVA は，著者らの報告に彷って4), 市販のポ リビニルアルコール(PVA)を $10 \%$ の水を含むメタノー ル中で, 所定量の過ヨウ素酸を用いて室温で, 1,2-グリ コール構造を部分的に切断し，切断により生じた，末端 にフルデヒド基を持つPVAを，約 10\%ポリマー濃度の

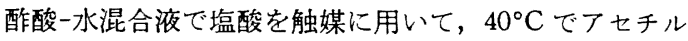
化と同時に分子間アセタール化して製造した。精製法, アセチル化度の測定法などは, 直鎖状 Ac-PVA の場合 と同様である。フセタール化前の PVA および分枝 AcPVAをアルカリケン化して得られる分枝 PVA の水溶 液の粘度から, 中島らの粘度式を用いで), それぞれの 粘度平均重合度 $(P)$ を求め, これらの值から(1)式によ。 $\tau$, 分枝 Ac-PVA の 100 基本分子あたりの分枝単位の 数 $B$ を算出した。

$$
\begin{aligned}
B & =\frac{\frac{P(\text { 分枝 })}{P(\text { 未分枝 })}-1}{P(\text { 分枝 })} \times 100 \\
& =\left\{\frac{1}{P(\text { 未分子 })}-\frac{1}{P(\text { 分枝 })}\right\} \times 100
\end{aligned}
$$

なお, 前述と同様に過ヨウ素酸分解後, 水溶液中で分子 間アセタール化して得られたフセチル基を含ま奴分枝 PVA の重合度は, アルカリ水溶液中で処理してもほと えど低下しなかったので，前述の分枝の Ac-PVA 分枝 も, アルカリケン化中にはほとえど切断されていないも のと考光られる。

ピニルアルコールーアリルアルコール共重合物 (PVAAA) およびビニルアルコールーイソプロペニルアルコー ル共重合物(PVA-IPA) は, 著者らの報告に従って6), 酢 酸ビニルを酷酸アリルまたは酷酸イソプロペニルと過酸 化ベンゾイルを触媒に用いて共重合させ, 得られた共重 合物を常法によりアルカリケン化して製造した。共重合 物中のモノマー組成は，モノマーの仕込みモル比とモノ マー反応性比を用いて算出した。これらの共重合物フル コールは, Ac-PVA の場合と同椂に酶酸-水中で部分的 にアセチル化した。

デンプンとしては市販のアミロース・アミロペクチン および可溶性デンプソを用いた。これらを混合組成の異 なる酶酸一水中で塩酸を触媒に用いて $40^{\circ} \mathrm{C}$ で長時間 セチル化した。反応液は最初は不均一であるが，反応の 進行に伴って均一となった。反応終了後の溶液は塩酸を 中和後, 透析により精製し, ケン化に要するアルカリ量
からアセチル化度を算出した。一部の実験においては, デンプンをホルムフミドに溶解後, 無水酶酸とピリジン を加えて 1 度完全に了セチル化した後》)、アセトンー水混 合液中で, 添加した所定量の水酸化ナトリウムが消費し つくされるまで部分ケン化したものを用いた。ケン化は 最初アセトン $8:$ 水 2 (容積比) 混合液中で行ない, ケン 化の進行に伴って順次水を加えて, 終始ほぼ均一系で行 なわせた。

本実験に用いた高分子ェステルの基本構造を，略号と ともに Fig. 1 に示す。<smiles>CCC(CC)CC(O)OC(C)=O</smiles>

(Ac-PVA)

linear and branched<smiles>CCC(CC(CO)CC(O)CC(C)COC(C)=O)C(C)=O</smiles>

(Ac-PVA-AA)

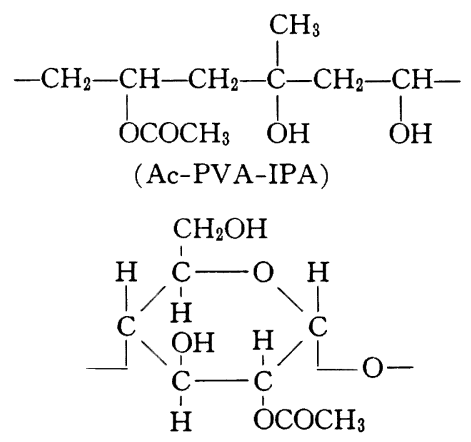

(Ac-S)

Fig. 1. Polymeric esters used in the experiment.

\section{2 触媒スルホン酸}

触媒スルホン酸としては, アタクチックポリスチレン を二塩化エチレン中でスルホン化したもの(S-PS), p-ス チレンスルホン酸ソーダを $27 \%$ 水溶液中でラジカル重 合して製造したもの(PSS), ラジカル重合ポリアセナフ チレンを前述と同様の方法で部分スルホン化したもの (S-PANa)，およびドデシルベンゼンスルホン酸 (DBS) を用いた。これらの製造，精製，分析法は既報1 3) と同 様であるので, 詳細は略す。

\section{3 ケン化反応}

ケン化実験の方法は既報1) 3) と同じであり，擬 1 分子 積分速度式を用いて見かけの速度定数 $k$ を求めた。既報 のように, この式から求めた $k$ の値は反応の進行に伴。 て一般にやや変化するので，15 20\%程度の比較的低い 反応率におけるデータから $k$ を求め, スルホン酸触媒の 
場合の $k\left(=k_{s}\right)$, 同一反応条件における塩 酸触媒の場合の $k\left(=k_{\mathrm{HCl}}\right)$ との比, $r=k_{s} / k_{\mathrm{HCl}}$ の值によって触媒効果を比較した。

\section{3. 結果および考察}

\section{1 分枝 Ac-PVA のケン化}

まず，分枝密度 $B$ が $0.40 / 100$ 基本分子で， 異なるアセチル化度を持つ分枝 Ac-PVAを PSS, S-PS, DBS および塩酸を触媒に用いて 同一条件でケン化した。この結果は Table 1 のとおりであり，ほぼ同一のアセチル化度で 比較すると，分枝 Ac-PVA に対する $r$ は一 般に直鎖 Ac-PVA に対するそれよりわずか に低い程度である。

次に，アセチル化度が約 14 モル\%で，分枝 密度の異なる Ac-PVA のケン化反応の $r$ 値 を比較した。この結果は Table 2 に示すとお りであり, 分枝密度の增加に伴って一般に $r$ は低下して去り，低下の程度は $r$ 值の比較的 小さいPSS では小さく, $r$ 值の比較的大きい S-PS (37.2) ではやや大きい。分枝密度の高 いAc-PVA は， 1 次鎖および分枝ポリマー の重合度がともにかなり低いが，既報のよう に1),3), 直鎖状 Ac-PVA のケン化反応におけ る $r$ 法この重合度に添無関倸であるので， 本実験で認められた分枝密度の異なる AcPVA 試料の $r$ の差異は，分枝の影響を直接 反映していると考えることができる。AcPVAに分枝が存在すると，スルホン酸との 結台が立体的に妨げられるために，r值が低 下したものと考えられる。しかし，本実験の

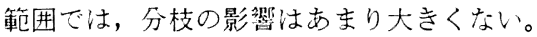

\section{2 ビニルアルコール共重合体の部分ア セチル化物のケン化}

次に，比較的少量のアリルアルコール，ま

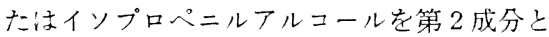
して含至ビニルアルコール共重合体のアセチ ル化物のケン化を行ない, 反応速度を $\mathrm{Ac}$ PVAの場合と比較した。これに関する実验 の条件と結果は,一括して Table 3 に示した。

Table 3 から次のことがわかる。Ac-PVA -AA の $k_{\mathrm{HCl}}$ は Ac-PVA のそれよりやや大 きい。このことから，前者の高分子エステル において泣，ビニルアルコール基本分子以外 にアリルアルコール基本分子の一部もアセチ ル化されているものと考えられる。しかし， 同一アセチル化度における $r$ 㯈は両高分子エ ステルではほぼ同じであり, PVA 鎖に20モ
Table 1. Hydrolysis of partially acetylated linear and branched polyvinyl alcohols (Ac-PVA) with sulfonic acids in water.

Branched Ac-PVA: DP before branching 186, DP after branching 695 , Density of branched units $0.40 / 100$ base mole units, Concentration of Ac-PVA $3.0 \mathrm{~g} / l$, Concentration of catalyst $0.0050 \mathrm{~N}$, Temp. $50^{\circ} \mathrm{C}$

\begin{tabular}{l|l|r|r|r|r|r|c}
\hline \hline \multirow{2}{*}{ Ac-PVA } & Branching & - & + & - & + & - & + \\
\cline { 2 - 7 } & $\begin{array}{l}\text { Acetylation } \\
\text { degree (mol\%) }\end{array}$ & 14.2 & 14.2 & 24.6 & 24.2 & 34.1 & 33.9 \\
\hline \multirow{2}{*}{$k_{s} / k_{\mathrm{HCl}}$} & PSSa) & 9.0 & 9.0 & 14.5 & 12.8 & 22.2 & 19.8 \\
& S-PS (37.2) $)$ & 25.6 & 23.3 & 33.3 & 29.0 & 40.1 & 38.0 \\
& DBSc) & 15.8 & 14.7 & 16.0 & 14.8 & 16.8 & 15.6 \\
\hline
\end{tabular}

a) Polystyrene sulfonic acid

b) Sulfonated polystyrene (degree of sulfonation $37.2 \mathrm{~mol} \%$ )

c) Dodecylbenzene sulfonic acid

Table 2. Hydrolysis of partially acetylated polyvinyl alcohols having different density of branching with sulfonic acids in water.

Concentration of Ac-PVA $3.0 \mathrm{~g} / \mathrm{l}$, Concentration of catalyst $0.0050 \mathrm{~N}$, Temp. $50^{\circ} \mathrm{C}$

\begin{tabular}{c|l|r|r|r|r}
\hline \hline \multirow{4}{*}{ Ac-PVA } & $\begin{array}{l}\text { DP before branching } \\
\text { DP after branching } \\
\text { Number of branchs } \\
\text { (per 100 base mol) }\end{array}$ & 456 & 186 & \multicolumn{1}{c|}{50} & \multicolumn{1}{c}{50} \\
& Acetylation degree (mol\%) & 14.2 & 14.7 & 14.0 & 14.7 \\
\hline$r$ & PSS & 9.0 & 9.0 & 11.4 & 8.7 \\
& S-PS (37.2) & 25.6 & 23.3 & 16.6 & 13.2 \\
& DBS & 15.8 & 14.7 & 12.6 & 10.4 \\
\hline
\end{tabular}

Table 3. Hydrolysis of partially acetylated vinyl alcohol copolymers with sulfonic acids in water.

Concentration of substrate $3.0 \mathrm{~g} / \mathrm{l}$, Concentration of catalyst $0.0050 N$, Temp. $50^{\circ} \mathrm{C}$

\begin{tabular}{|c|c|c|c|c|c|c|}
\hline \multicolumn{3}{|c|}{ Substrate } & \multicolumn{3}{|c|}{$r=k_{s} / k_{\mathrm{HCl}}$} & \multirow{2}{*}{$\begin{array}{c}k_{\mathrm{HCl}} \\
\times 10^{3}\end{array}$} \\
\hline $\begin{array}{l}\text { Comono- } \\
\text { mer }\end{array}$ & $\begin{array}{c}\text { Mol\% } \\
\text { of } \\
\text { comono- } \\
\text { mer }\end{array}$ & $\begin{array}{c}\text { Acetyla- } \\
\text { tion } \\
\text { degree } \\
(\mathrm{mol} \%)\end{array}$ & PSS & $\begin{array}{c}\text { S-PS } \\
(41)\end{array}$ & DBS & \\
\hline \multirow{3}{*}{ None } & 0 & 14.2 & 9.0 & 25.6 & 15.8 & 10.5 \\
\hline & 0 & 23.3 & 13.0 & 34.8 & 16.0 & 9.5 \\
\hline & 0 & 27.0 & 17.5 & 39.1 & 15.2 & 8.7 \\
\hline \multirow{2}{*}{$\begin{array}{l}\text { Allyl- } \\
\text { alcohol }\end{array}$} & 5.6 & 23.4 & 12.3 & 32.0 & 13.5 & 12.0 \\
\hline & 21.3 & 27.3 & 16.7 & 43.1 & 16.7 & 15.0 \\
\hline \multirow{2}{*}{$\begin{array}{l}\text { iso- } \\
\text { Propenyl- } \\
\text { alcohol }\end{array}$} & 4.1 & 20.4 & 12.3 & 23.5 & 12.6 & 9.5 \\
\hline & 17.8 & 17.8 & 17.6 & 35.1 & 15.2 & 8.9 \\
\hline
\end{tabular}


ル\%程度のフリルフルコール単位を導入しても, スルホ ン酸との結合はあまり影響を受けないと考えられる。

他方, Ac-PVA-IPA の $k_{\mathrm{HCl}}$ は Ac-PVA のそれとほ ほ同じであり，前者のエステル分子中のア七チル基は， 主としてビニルアルコール基本分子に結合しているもの と考えられる。両高分子エステルの同一アセチル化度に おける $r$ 值を比較すると,イソプロペニルアルコールの 含量が 4.1 モル\%の場合は同程度であるが，この含量が 17.8 モ $\%$ の Ac-PVA-IPA の $r$ は, PSS および S-PS 触媒の場合には, Ac-PVAよりもやや大きい。この結果 から,イソプロペニルアルコール単位中のメチル基が, 高分子スルホン酸との結合を少し強める働きをしている ものと思われる。しかしこの場合においても，r值の 差異は比較的小さい。

\section{3 部分アセチル化デンプンのケン化}

次にAc-S を高分子エステルに用いて，同様なケン化 実験を行なった。0.005 N の一定触媒濃度で行なった実 験結果は，一括して Table 4 に示した。

Table 4 においてまず目につくことは, Ac-S の r值が 同一ア七チル化度の Ac-PVAのそれよりも一般に著し く小さいことである。ここに用いたスルホン酸はいずれ

Table 4. Hydrolysis of partially acetylated starchs with sulfonic acids in water.

Concentration of substrate $3.0 \mathrm{~g} / \mathrm{l}$, Concentration of catalyst $0.0050 \mathrm{~N}$, Temp. $50^{\circ} \mathrm{C}$

\begin{tabular}{|c|c|c|c|c|c|c|c|}
\hline \multicolumn{3}{|c|}{ Substrate } & \multicolumn{4}{|c|}{$r=k_{s} / k_{\mathrm{HCl}}$} & \multirow{2}{*}{$\left(\begin{array}{c}k_{\mathrm{HCl}} \\
l \cdot \mathrm{mol}^{-1} \\
\mathrm{~min}^{-1}\end{array}\right)$} \\
\hline $\begin{array}{l}\text { Parent } \\
\text { starch }\end{array}$ & $\begin{array}{c}\text { Acetyla- } \\
\text { tion } \\
\text { degree } \\
(\mathrm{mol} \%)\end{array}$ & $\begin{array}{l}\left.\eta_{s p} / C^{a}\right) \\
(\mathrm{d} l / g)\end{array}$ & PSS & $\begin{array}{l}\text { S-PS } \\
(37)\end{array}$ & $\begin{array}{c}\text { S-P) } \\
(81)\end{array}$ & DBS & \\
\hline \multirow{2}{*}{$\begin{array}{c}\text { Soluble } \\
\text { starch }\end{array}$} & 12.8 & 0.20 & 0.91 & 0.74 & 0.40 & 1.9 & 21.0 \\
\hline & 13.5 & 0.20 & 0.89 & 0.84 & 0.42 & 2.0 & 18.0 \\
\hline \multirow{4}{*}{$\begin{array}{c}\text { Amylo- } \\
\text { pectin }\end{array}$} & 13.8 & 0.27 & 0.87 & 0.68 & 0.32 & 2.0 & 20.8 \\
\hline & 17.2 & 0.16 & 0.78 & 0.94 & - & 1.7 & 17.8 \\
\hline & 27.3 & 0.03 & 0.94 & 1.73 & 0.67 & 1.7 & 15.2 \\
\hline & $28.0^{c)}$ & 0.61 & 0.69 & 7.4 & - & 5.4 & 9.1 \\
\hline \multirow{5}{*}{ Amylose } & 9.4 & 0.23 & 1.0 & 1.5 & 0.35 & 1.8 & 21.9 \\
\hline & 16.7 & 0.23 & 0.91 & 1.3 & - & 2.1 & 18.4 \\
\hline & 22.3 & 0.23 & 1.1 & 2.0 & - & 2.0 & 18.6 \\
\hline & 28.5 & 0.23 & 0.99 & 2.0 & 0.77 & 2.0 & 15.0 \\
\hline & $28 \cdot 3^{c)}$ & 0.38 & 0.82 & 18.1 & - & 4.7 & 8.8 \\
\hline
\end{tabular}

a) The values were determined in aqueous solution of $0.3 \mathrm{~g} / \mathrm{d} l$ at $30^{\circ} \mathrm{C}$.

b) Partially sulfonated $(81 \mathrm{~mol} \%)$ polyacenaphthylene

c) The samples were obtained by partial hydrolysis of completely acetylated starchs with $\mathrm{NaOH}$ in acetone-water mixtures; the other samples were obtained by partial acetylation of starchs in acetic acid-water mixtures.
も，Ac-PVAのケン化に対しては1よりずっと大きいr 值を示したが, Ac-S のケン化に対しては塩酸と同程度, あるいはそれ以下の触媒作用しか示さない場合が多い。 デンプン分子においては，くり返し単位が大きく，かつ， 空間的にかさばっている。このために, 触媒スルホン酸 との結合に対して, 近接基の共同効果が現われにくく, Ac-PVA の場合よりも小さい $r$ 值しか示さなかったも のと思われる。

次に, 個々のエステルースルホン酸采をながめる。PSS はいずれの Ac-S 試料に対しても, 塩酸と同程度, ある いはそれ以下の触媒作用しか示さない。S-PS (37) はフ 七チル化度の低い可溶性デンプンおよびアミロペクチン に対しては，塩酸以下の触媒作用しか示さないが，丁セ チル化度の高いてセチル化アミロペクチン，およびアセ チル化厂ミロース一般に対しては，塩酸より大きい触媒 作用を示す。興味あることに，フセチル化度がほぼ同一 の Ac-S 試料においても，1度完全にアセチル化後, 部 分ケン化して製造した試料のほうがずっと大きい $r$ 值が 得られる。また, この試料の $k_{\mathrm{HCl}}$ は, 直接部分厂七チ ル化物のそれよりかなり低い。著者らは，PVAを酢酸一 水采で部分了セチル化すると, フセチル基は高分子鎖に 沿って統計的にほほ無秩序に導入される が，ポリ酶酸ビニルを含水厂セトン中で アルカリケン化すると, 分子鎖に沿って アセチル基が比較的集団的に配列してい る Ac-PVA が得られることを報告して いる8)。また既報のように1)，アセチル基 が集団的に配列しているAc-PVA はフ セチル基が無秩序に導入されている試料 に比べて, S-PS 触媒によるケン化反応 のr值が明らかに大きく，塩酸触媒によ るケン化速度はかなり小さい。これらの 結果から, Ac-S の場合にも, 再ケン化 法によって製造された試料は，アセチル 基が比較的集団的に存在するために SPS との疎水性結合を起こしやすく，し たがって大きい $\boldsymbol{r}$ 值を示したものと，一 応解釈できる。

$\mathrm{S}-\mathrm{PANa}(81)$ の触媒作用は一般に塩酸 より明らかに小さく,かつ, PSSよりも 小さい。この傾向は Ac-PVA の場合と 全く異なる。S-PANa は側鎖基がかさ高 いために Ac-Sにほとえど結合されず， かつ，ケン化反応の遝移状態形成に対す む立体活吉が大きいためにこのような 結果を生じたものと思われる。

DBS 触媒の場合の $r$ 值は, Ac-PVAの ケン化のときよりはずっと小さいが，一 
般に 1 よりは大きく, かつ, $r$ 值は Ac-S 試料の種類に 比較的不鋭敏である。DBS を触媒に用いたときの $r$ 值 が高分子ェステルの構造に比較的不鋭敏であることは， 既報の Ac-PVA のケン化の場合にも認められている1)。

$\mathrm{Ac}-\mathrm{S}$ の原料デンプンに着目すると, 直鎖状のアミロ 一スの部分アセチル化物のほうが，分枝状のアミロペク チンの部分アセチル化物よりも一般に $r$ 值が大きい。こ れは 3.1 で述べた Ac-PVA の場合と同じ傾向にあり， 高分子ェステルの分枝は触媒スルホン酸上の結合を妨げ るものと考えられる。

以上の実験は $0.005 \mathrm{~N}$ の触媒濃度で行なったが，次に 触媒莀度を变更して若干の実験を行なった。この結果は Table 5 に示すとおりであり，r值は触媒濃度の上昇に 伴って, S-PS の場合はやや低下し, DBS の場合にはや や増大している。この傾向は Ac-PVA のときと同様で

Table 5. Hydrolysis of partially acetylated starchs with sulfonic acids in different concentrations. Concentration of substrate $3.0 \mathrm{~g} / \mathrm{l}$, Temp. $50^{\circ} \mathrm{C}$

\begin{tabular}{|c|c|c|c|c|}
\hline \multicolumn{2}{|c|}{ Substrate } & \multirow{2}{*}{$\begin{array}{c}\text { Concentra- } \\
\text { tion of } \\
\text { catalyst } \\
(N)\end{array}$} & \multicolumn{2}{|c|}{$r=k_{s} / k_{\mathrm{HCl}}$} \\
\hline $\begin{array}{l}\text { Parent } \\
\text { starch }\end{array}$ & $\begin{array}{c}\text { Acetylation } \\
\text { degree } \\
(\text { mol } \%)\end{array}$ & & $\begin{array}{c}\text { S-PS } \\
(37)\end{array}$ & DBS \\
\hline \multirow{3}{*}{$\begin{array}{l}\text { Soluble } \\
\text { starch }\end{array}$} & 12.8 & 0.002 & 0.79 & 1.6 \\
\hline & 12.8 & 0.005 & 0.74 & 1.9 \\
\hline & 12.8 & 0.020 & 0.64 & 1.9 \\
\hline \multirow{3}{*}{$\begin{array}{l}\text { Amylo- } \\
\text { pectin }\end{array}$} & 17.2 & 0.002 & 1.12 & 1.3 \\
\hline & 17.2 & 0.005 & 0.94 & 1.7 \\
\hline & 17.2 & 0.020 & 0.71 & 2.2 \\
\hline \multirow{3}{*}{ Amylose } & 22.3 & 0.002 & 2.3 & 1.5 \\
\hline & 22.3 & 0.005 & 2.0 & 2.0 \\
\hline & 22.3 & 0.020 & 1.9 & 2.0 \\
\hline
\end{tabular}

ある污，r值が小さいためにその変化も小さい。

\section{4. 結言}

以上のように, Ac-PVA のケン化反応に対するスルホ ン酸の触媒作用は, Ac-PVA 分子に少量の分枝, アリル アルコール単位，あるいはイソプロペニルアルコール単 位を導入してもあまり变化しない。この事実も，触媒下 ルホン酸との結合に対して，高分子ェステルの分子全体 ではなく，比較的短い鎖部分の共同効果が重要であると いう既報の考えを支持している。

Ac-S のケン化反応における $r$ 值は，一般に Ac-PVA の場合よりもずっと小さい。このように，高分子アルコ ールの部分フセチル化物でも，出発高分子アルコールの 構造によって，r值，したがって触媒スルホン酸との結 合性が著しく相違することは興味深く,この点は今後の 系統的な検討が必要である。

\section{文献}

1）桜田一郎, 坂口康義, 大村恭弘：高化， 23，735 (1966)

2）桜田一郎，大村恭弘，坂口康義：高化， 23，741 (1966)

3）桜田一郎, 坂口康義, 大村恭弘： 高化，23, 印刷 中

4）桜田一郎，松沢秀二：高化，16，90 (1959)

5) 中島章夫, 古館正勝：高化，6, 460 (1949)

5）桜田一郎, 高橋儀作：高化，11，344 (1954)；13, 497 (1956)

6）桜田一郎, 坂口康義, 岩城正守：高化，11，344 (1954)； 13, 497 (1956)

7) A. L. Potter, W. Z. Hassid: J. Am. Chem. Soc., 70, 3774 (1948)

8）兴田一郎, 坂口康義, 岩城正守: 高化, 13, 403 (1956); 桜田一郎, 坂口康義: 高化, 13, 441(1956); その他

\title{
Hydrolysis of Polymeric Esters with Polymeric Sulfonic Acids III. Hydrolysis of Partially Acetylated Products of Modified Polyvinyl Alcohols and Starchs with Polymeric Sulfonic Acids
}

\author{
By Ichiro Sakurada*, Yasuhiro Ohmura* and Yasuyoshi Sakaguchi**
}

Partially acetylated products of branched polyvinyl alcohols (PVA) (branched units $<1.3 / 100$ unit molecules), vinyl alcohol-allyl alcohol copolymers (mol \% of allyl alcohol $<22$ ) and vinyl alcohol-isopropenyl alcohol copolymers (mol\% of isopropenyl alcohol $<18$ ) were hydrolyzed with polystyrene sulfonic acid, partially sulfonated polystyrene and dodecylbenzene sulfonic acid in

* Department of Polymer Chemistry, Kyoto University (Kyoto)

** Department of Applied Chemistry, Kōnan University (Higashinada-ku, Kōbe) 
water, and the rate constants of hydrolysis $\left(k_{s}\right)$ were compared to those of hydrolysis carried out under the same condition with hydrochloric acid $\left(k_{\mathrm{HCl}}\right)$. Generally the values of $r=k_{s} / k_{\mathrm{HCl}}$ for acetates of these modified PVA were near those for acetates of linear unmodified PVA. Partially acetylated starchs were also hydrolyzed, and it was found that the $r$-values were much smaller than those for partially acetylated PVA of the same acetylation degree. The $r$-value for partially acetylated amylose was somewhat greater than that for partially acetylated amylopectin. Some discussions were given for these results. 